\title{
Analisis Pengaruh Motivasi dan Disiplin Belajar Pada Pembelajaran Daring di Masa Pandemi Covid-19
}

\author{
Iqbal Muhammad Syaifullah, Riswanti Rini, Ujang Efendi, Lilik \\ Sabdaningtyas \\ Pendidikan Guru Sekolah Dasar, Universitas Lampung \\ Jl. Prof. Dr. Sumantri Brojonegoro No 1 Bandar Lampung \\ E-mail: igbalmsyaifullah@gmail.com
}

\begin{abstract}
Article Info
Abstract

Received Januari 2021

Accepted April 2021

Published April 2021

Keywords:

motivation, discipline, learning outcomes, mathematics for elementary school

The objective of this research was to analyze the effect of learning motivation on learning outcomes, the influence of learning discipline on learning outcomes, and the influence of motivation and learning discipline on learning outcomes during online learning. This research was a quantitative research with ex post facto method. The population of this research amounted to 136 students. The sampling technique used was probability sampling using a simple random sampling technique with the outcomes of 58 students. The data collection technique used was a questionnaire to collect data on student answers and documentation in order to obtain data on learning outcomes. The data analysis techniques used was multiple linear regression test. The outcomes of this research indicated that there was an influence between learning motivation on learning outcomes of $62.7 \%$, learning discipline on learning outcomes of $37.3 \%$, and simultaneously learning motivation and learning discipline on mathematics learning outcomes of $65.6 \%$. The conclusion of this study shows that there is an influence between learning motivation and learning outcomes, learning discipline and learning outcomes as well as learning motivation and learning discipline on mathematics learning outcomes in fourth grade students.
\end{abstract}

\begin{abstract}
Abstrak : Tujuan penelitian ini untuk menganalisis pengaruh antara motivasi belajar terhadap hasil belajar, pengaruh antara disiplin belajar terhadap hasil belajar dan pengaruh antara motivasi dan disiplin belajar terhadap hasil belajar selama pembelajaran dalam jaringan. Penelitian ini termasuk jenis penelitian kuantitatif dengan desain korelasional dan menggunakan metode ex post facto. Populasi penelitian ini berjumlah 136 peserta didik. Teknik pengambilan sampel yang dipakai yaitu probability sampling menggunakan teknik simple random sampling dengan hasil 58 peserta didik. Teknik pengumpulan data dalam penelitian ini menggunakan kuesioner guna pengumpulan data jawaban peserta didik dan dokumentasi guna memperoleh data hasil belajar. Teknik analisis data menggunakan uji regresi linear berganda. Hasil penelitian ini menunjukkan ada pengaruh antara motivasi belajar terhadap hasil belajar sebesar $62,7 \%$, disiplin belajar terhadap hasil belajar sebesar $37,3 \%$ dan secara simultan motivasi belajar serta disiplin belajar terhadap hasil belajar matematika sebesar $65,6 \%$. Kesimpulan penelitian ini menunjukkan bahwa terdapat pengaruh antara motivasi belajar dan hasil belajar, disiplin belajar dan hasil belajar serta motivasi belajar dan disiplin belajar terhadap hasil belajar matematika pada siswa kelas IV.
\end{abstract}

Kata Kunci: motivasi, disiplin, hasil belajar, matematika SD

C2021 Jurusan Ilmu Pendidikan, FKIP Universitas Lampung 


\section{PENDAHULUAN}

Secara sederhana dan umum, pendidikan bermakna sebagai usaha untuk menumbuhkan dan mengembangkan potensi-potensi bawaan, baik jasmani maupun rohani, sesuai dengan nilai-nilai yang ada di dalam masyarakat dan kebudayaan (Yuristia, 2018). Pendidikan sendiri merupakan wadah dimana peserta didik dapat secara aktif untuk belajar dan mengembangkan potensi yang ada pada dirinya sehingga mereka dapat memiliki akhlak yang baik serta kecerdasan dan keterampilan untuk membangun bangsa dan negara menjadi lebih baik dengan cara memperoleh pengetahuan yang ditempuh dengan melakukan usaha-usaha belajar baik formal maupun informal.

Usaha belajar yang dilakukan oleh siswa pada dampaknya akan terlihat dengan ditunjukkannya hasil belajar yang baik sebagai akibat dari proses transfer ilmu yang ia lakukan sendiri dengan metode yang sesuai dengan motivasi belajar yang ia inginkan sehingga tiap proses pembelajaran menjadi bermakna. Motivasi adalah suatu kekuatan atau daya atau suatu keadaan yang kompleks dan kesiapsediaan dalam diri individu untuk bergerak ke arah tujuan tertentu, dan dipengaruhi oleh adanya berbagai macam kebutuhan yang hendak dipenuhi, keinginan, dan dorongan, yaitu sesuatu yang memaksa seseorang untuk berbuat atau bertindak (Khodijah, 2016). Motivasi belajar juga merujuk kepada harapan dan nilai, dimana harapan menunjukkan bahwa siswa mampu untuk menyelesaikan tugas yang diberikan dan nilai menunjukkan keyakinan siswa secara kuat untuk berhasil dalam belajar. Jadi dapat dikatakan motivasi akan senantiasa menentukan intensitas usaha belajar bagi para siswa sehingga hasil belajar siswa akan semakin meningkat. Sedangkan disiplin merupakan suatu tindakan yang menunjukkan perilaku tertib dan patuh pada berbagai ketentuan dan peraturan (Indrianti, 2018).

Disiplin juga merupakan kesediaan untuk (taat, tunduk, nurut, patuh) pada aturan, norma-norma (baik norma agama maupun norma kesusilaan) baik yang tertulis maupun tidak tertulis, baik didalam lingkungan (keluarga, sekolah dan masyarakat), merupakan arahan untuk melatih dan membentuk seseorang untuk melakukan sesuatu menjadi lebih baik. Belajar dapat dikatakan berhasil apabila peserta didik dapat menguasai materi pelajaran yang diberikan sekolah yang diwujudkan dalam hasil belajar yang baik. 
(Molstad \& Karseth 2016) menyatakan "learning outcomes as the competences and skills that pupils will have after a period of learning". Pendapat tersebut diartikan bahwa hasil belajar dapat didefinisikan sebagai kompetensi dan keterampilan yang dimiliki siswa setelah masa pembelajaran.

Dampak pandemi Covid-19 yang kini mulai merabah pada dunia pendidikan, membuat Presiden dan Mendikbud melakukan rapat terbatas dan melihat perkembangan penyebaran Covid-19, sehingga pada tanggal 24 Maret Mendikbud mengeluarkan Surat Edaran (SE) Nomor 4 Tahun 2020 tentang pelaksanaan Kebijakan Pendidikan dalam Masa Darurat Penyebaran Coronavirus Disease (Covid-19). Surat Edaran tersebut untuk ditunjukan kepada para Gubernur, dan Bupati/ Walikota di seluruh Indonesia dengan tembusan kepada seluruh Kepala Dinas Pendidikan Provinsi, seluruh Kepala Dinas Kabupaten/ Walikota dan Kepala seluruh Satuan Pendidikan. Covid-19 adalah virus jenis baru yang belum pernah diidentifikasi sebelumnya pada manusia, sehingga pada tanggal 30 Januari 2020 World Health Organization (WHO) telah menetapkan sebagai kedaruratan kesehatan masyarakat yang meresahkan dunia (Zhou et al.,2020).

Surat Edaran tersebut berisi beberapa hal mengenai pendidikan, salah satunya adalah proses belajar dari rumah melalui pembelajaran daring/ jarak jauh. Sehingga dengan adanya pembelajaran daring, kegiatan pembelajaran pada sekolah dan kampus yang biasanya dilakukan secara konvensional, kini semua harus dilakukan dengan pembelajaran daring guna memutus mata rantai penyebaran virus corona.

Pembelajaran daring membuat peserta didik menjadi memiliki keleluasaan waktu untuk belajar serta peserta didik tidak harus datang kesekolah, melainkan pembelajaran dilakukan melalui jarak jauh sehingga peserta didik melakukan pembelajaran secara mandiri dirumah. Pembelajaran pada hakikatnya adalah suatu proses, yaitu proses mengatur, mengorganisasi lingkungan yang ada di sekitar peserta didik sehingga dapat menumbuhkan dan mendorong peserta didik melakukan proses belajar (Pane dan Dasopang, 2017). Pembelajaran daring lebih menekankan pada ketelitian dan kejelian peserta didik dalam menerima dan mengolah informasi yang disajikan secara online. Sehingga dengan diterapkannya metode pembelajaran dalam jaringan membuat siswa menjadi kesulitan untuk melalui proses belajar, adapun 
kekurangan dalam pembelajaran daring mengakibatkan kurangnya interaksi antara guru dan siswa bahkan antar-siswa itu sendiri (Hadisi \& Muna, 2015).

Peneliti menduga motivasi belajar dan disiplin belajar menjadi hal yang mempengaruhi dalam tercapainya hasil belajar yang baik bagi peserta didik selama pembelajaran daring. Faktor faktor keberhasilan pembelajaran daring itu sendiri terbagi menjadi dua, yaitu faktor dari dalam yang diantaranya berupa motivasi dan faktor dari luar yang berupa disiplin. Motivasi dan disiplin merupakan dua hal yang dapat saling melengkapi untuk menunjang keberhasilan proses suatu pembelajaran terlebih pada saat ini peserta didik melakukan usaha belajar secara mandiri tanpa didampingi guru secara langsung seperti di dalam kelas.

Hasil belajar itu sendiri adalah kemampuan- kemampuan yang dimiliki siswa setelah ia menerima pengalaman belajarnya (Sudjana, 2016). Hasil belajar pada dasarnya merupakan hal yang sangat penting dalam pendidikan karena menjadi salah satu alat ukur sejauh mana tingkat pemahaman peserta didik dalam memahami suatu materi. Namun, pada kenyataannya tidak semua peserta didik berhasil melalui proses belajar yang mereka ikuti, terlebih saat ini peserta didik dihadapi dengan pembelajaran daring. Pembelajaran daring dapat diartikan sebagai pendekatan inovatif dalam menyampaikan pembelajaran yang (1) telah dirancang dengan baik, (2) berpusat pada pembelajar (learned centered), (3) interaktif dan (4) dapat memfasilitasi pembelajaran untuk siapa saja, dimana saja dan kapan saja dengan memanfaatkan atribut dan beragam sumber bersama dengan bahan ajar lain yang tepat untuk digunakan dalam lingkungan belajar yang bersifat open (terbuka), flexible (fleksibel), dan distributed (terdistribusi).

Pembelajaran daring merupakan hal yang baru bagi peserta didik, orang tua, maupun guru yang pada biasanya pada mata pelajaran matematika khususnya, secara konvensional guru memotivasi serta menjelaskan materi secara langsung terhadap peserta didik, dan kini hanya melalui grup whatsapp sebagai perantara pembelajaran sehingga hal ini berdampak dengan adanya nilai hasil belajar peserta didik yang masih rendah, salah satu diantaranya yaitu pelajaran Matematika. berdasarkan penelitian pendahuluan yang dilakukan didapatkan data hasil ujian tengah semester para peserta didik kelas IV pada pembelajaran matematika, dari total keseluruhan peserta didik yang 
berjumlah 136, terdapat 78 peserta didik atau 57,35\% yang belum mencapai KKM. Rendahnya hasil belajar tersebut menunjukkan bahwa tujuan pembelajaran di SD Negeri Gugus Bumi Waras tersebut belum tercapai, karena hasil belajar belum mencapai KKM yang diberlakukan untuk mata pelajaran Matematika yaitu 60 .

Matematika itu sendiri merupakan suatu ilmu yang sangat penting bagi kehidupan, hal tersebut sesuai karena matematika merupakan salah satu disiplin ilmu yang dapat meningkatkan kemampuan dalam berpikir dan berargumentasi, memberikan kontribusi dalam penyelesaian masalah seharihari dan dalam dunia kerja serta memberikan dukungan dalam pengembangan ilmu pengetahuan dan teknologi (Susanto, 2013).

Motivasi dan sikap disiplin, kedua sikap tersebut harus dimiliki dan dikembangkan sendiri oleh peserta didik yang dapat menjadi faktor pendukung terhadap proses belajar sehingga tujuan pembelajaran dan hasil belajar yang memuaskan akan diperoleh peserta didik. Dengan demikian dalam tulisan ini peneliti akan membahas mengenai pengaruh motivasi dan disiplin belajar terhadap hasil belajar matematika peserta didik kelas IV pada pembelajaran dalam jaringan.

\section{METODE}

\section{Jenis Penelitian}

Penelitian ini menggunakan jenis penelitian kuantitatif dengan desain penelitian korelasional dan menggunakan metode ex post facto.

\section{Populasi dan Sampel}

Penelitian dilaksanakan di SD Negeri Gugus Bumi Waras yang terdiri dari SD 3 Bumi Waras, SD 4 Bumi Waras, SD 5 Bumi Waras Kecamatan Bumi Waras pada peserta didik kelas IV. Populasi pada penelitian ini adalah para peserta didik kelas IV di SD Negeri Gugus Bumi Waras yang berjumlah 136 peserta didik. Sampel dalam penelitian ini berjumlah 58 peserta didik yang diuji menggunakan teknik probability sampling yaitu simple random sampling dengan metode undian. 


\section{Instrumen Penelitian}

Instrumen penelitian yang digunakan dalam penelitian ini adalah berupa kuesioner dan dokumentasi. Metode angket atau kuesioner merupakan metode pengumpulan data dengan cara memberi seperangkat pertanyaan atau pernyataan tertulis kepada responden untuk di jawabnya (Sugiyono, 2014). Kuesioner pada penelitian ini digunakan untuk memperoleh data mengenai Motivasi dan Disiplin belajar siswa selama pembelajaran daring kelas IV di SD Negeri Gugus Bumi Waras Bandar Lampung. Adapun angket atau kuesioner yang digunakan dalam penelitian ini adalah angket tertutup dengan 21 butir pertanyaan untuk angket motivasi dan 17 butir pertanyaan untuk angket disiplin yang dikembangkan berdasarkan indikator-indikator tiap variabel yang diteliti dan untuk mengukur skala skor kuesioner digunakan skala Likert. Dokumen yang diperoleh dalam penelitian ini berupa data hasil Ujian Tengah Semester Ganjil peserta didik kelas IV pada pembelajaran Matematika yang diperoleh dari kepala sekolah yang bersangkutan. Variabel terikat dalam penelitian ini adalah hasil belajar. Sedangkan variabel bebas yaitu motivasi belajar dan disiplin belajar.

\section{Prosedur Penelitian}

Tahapan yang dilakukan dalam penelitian ini terbagi atas beberapa kegiatan, diantaranya adalah uji instrumen berupa uji validitas angket, validitas adalah suatu ukuran yang menunjukkan tingkat-tingkat kevalidan atau kesahihan suatu instrumen (Arikunto, 2010). Selanjutnya uji reliabilitas angket, untuk mengukur sejauh mana alat ukur yang digunakan dapat dipercaya. Tahapan berikutnya adalah melakukan uji asumsi yang terdiri dari uji normalitas dan uji linieritas. Uji normalitas dilakukan untuk mengetahui apakah data yang terkumpul berdistribusi normal atau tidak normal, sedangkan uji linieritas bertujuan untuk mengetahui apakah dua variabel memiliki hubungan yang linear atau tidak (Sugiyono, 2014). Tahapan yang terakhir yaitu uji hipotesis dengan menggunakan uji regresi linier berganda, karena dalam penelitian ini memiliki lebih dari 2 variabel yang diteliti. Variabel akan dibagi menjadi variabel dependen/terikat (Y) dan variabel independen/bebas $(\mathrm{X})$. 


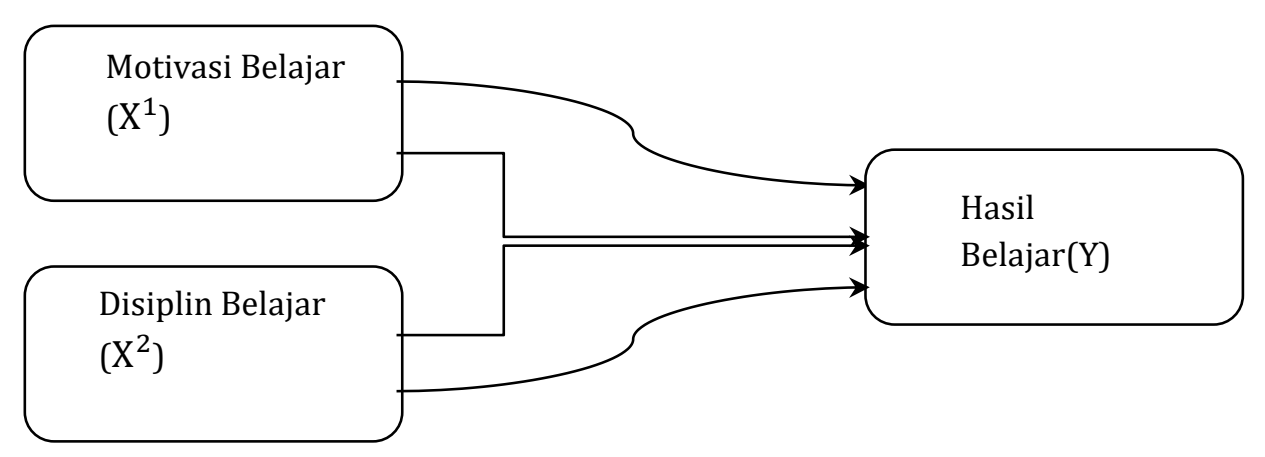

Gambar 1. Kerangka Pikir Penelitian

\section{Teknik Analisis Data}

Analisis ini menunjukan bahwa variabel dependen akan terpengaruh (bergantung) pada lebih dari satu variabel independen. Jadi analisis regresi linier berganda digunakan untuk mengetahui pengaruh baik secara parsial maupun simultan motivasi belajar dan disiplin belajar terhadap hasil belajar peserta didik di kelas IV Sekolah Dasar Negeri Gugus Bumi Waras. Secara parsial hasil uji regresi linear berganda akan menghasilkan besaran pengaruh sumbangan prediktor yang akan diuji dan menjadi penjabaran dari besarnya kontribusi pengaruh yang diberikan oleh masing-masing variabel. Sumbangan prediktor dikelompokkan menjadi 2 macam, yaitu sumbangan efektif (SE) dan sumbangan Relatif (SR).

Sumbangan Efektif merupakan suatu variabel independen terhadap variabel dependen dalam analisis regresi. Penjumlahan dari SE semua variabel independen adalah sama dengan jumlah nilai $\mathrm{R}$ Square (R2). Sumbangan Relatif merupakan suatu ukuran yang menunjukkan besarnya sumbangan suatu variabel independen terhadap jumlah kuadrat regresi. Jumlah SR dari semua variabel independen adalah $100 \%$ atau sama dengan 1 .

\section{HASIL}

Langkah pertama sebelum penelitian dilaksanakan, terlebih dahulu peneliti melakukan uji validasi oleh ahli. Pada penelitian ini, validasi dilakukan oleh salah satu dosen Universitas Lampung, kemudian dilanjutkan dengan Validitas eksternal yaitu validitas yang diperoleh dengan cara mengkorelasikan kuesioner dengan tolak ukur eksternal yang sudah valid. Validitas dilakukan dengan uji coba kuesioner pada 15 responden diluar sampel penelitian yaitu di 
SD Negeri 1 Panjang Utara pada siswa kelas IV yang \pm memiliki karakteristik yang serupa dengan populasi penelitian. Penghitungan data dalam penelitian ini diolah menggunakan program SPSS versi 25.

Hasil uji persyaratan instrumen pada uji validitas angket, dengan menggunakan rumus korelasi product moment diperoleh hasil untuk angket motivasi belajar dari 21 butir pertanyaan terdapat 4 butir soal yang tidak valid pada nomor 6, 9, 19 dan 21 dan 17 butir soal valid yang dapat digunakan untuk penelitian. Hasil pada angket disiplin belajar dari 17 butir pertanyaan terdapat 3 butir soal yang tidak valid pada nomor 9, 10 dan 17 dan 14 butir soal valid yang dapat digunakan untuk penelitian.

Hasil uji reliabilitas angket motivasi belajar menunjukan bahwa reliabilitas item-item soal tes berkategori tinggi dan dapat digunakan dengan rincian untuk motivasi belajar nilai Cronbach's Alpha adalah sebesar 0,885 dan nilai untuk angket disiplin belajar sebesar nilai Cronbach's Alpha adalah sebesar 0,917 .

Hasil uji prsayarat pada penelitian ini berupa uji normalitas dan uji linieritas. Uji normalitas untuk variabel Motivasi Belajar (X1) setelah dilakukan uji menggunakan rumus chi kuadrat, dari responden yang berjumlah 58 peserta didik interpretasi dilakukan dengan membandingkan $x 2$ hitung dengan nilai $x 2$ tabel untuk $a=0,05$ dan derajat kebebasan $(\mathrm{db})=\mathrm{k}-3=7-3=$ 4, maka dikonsultasikan pada tabel Chi Kuadrat didapat $x 2$ tabel sebesar 9,4877, sehingga $x 2$ (hitung) $=7,886<x 2($ tabel $)=9,4877$ berarti data variabel $x 1$ (Motivasi Belajar) berdistribusi data normal. Variabel Disiplin Belajar (X2) setelah dilakukan uji menggunakan rumus chi kuadrat, dari responden yang berjumlah 58 peserta didik interpretasi dilakukan dengan membandingkan $x 2$ hitung dengan nilai $x 2$ tabel untuk $a=0,05$ dan derajat kebebasan $(\mathrm{db})=\mathrm{k}-3=$ $7-3=4$, maka dikonsultasikan pada tabel Chi Kuadrat didapat $x 2$ tabel sebesar 9,4877 , sehingga $x 2$ (hitung) $=2,37<x 2($ tabel $)=9,4877$ berarti data variabel $x 2$ (Disiplin Belajar) berdistribusi data normal. Variabel Hasil Belajar (Y) setelah dilakukan uji menggunakan rumus chi kuadrat, dari responden yang berjumlah 58 peserta didik interpretasi dilakukan dengan membandingkan $x 2$ hitung dengan nilai $x 2$ tabel untuk $a=0,05$ dan derajat kebebasan $(\mathrm{db})=\mathrm{k}-3=7-3=$ 4, maka dikonsultasikan pada tabel Chi Kuadrat didapat $x 2$ tabel sebesar 
9,4877, sehingga $x 2$ (hitung) $=1,94<x 2($ tabel $)=9,4877$ berarti data variabel $Y$ (Hasil Belajar) berdistribusi data normal.

Uji Linieritas pada variabel Motivasi Belajar (X1) dengan membandingkan $\mathrm{F}$ hitung dan $\mathrm{F}$ tabel Jika $\mathrm{F}$ hitung $\leq \mathrm{F}$ tabel, artinya data berpola linier. Dari Hasil perhitungan dengan SPSS versi 25 diperoleh : hasil uji linearitas berupa nilai Sig. deviation from linearity sebesar 0,77 > 0,05, maka dapat disimpulkan bahwa terdapat hubungan yang linear antara motivasi belajar dengan hasil belajar matematika kelas IV. Variabel Disiplin Belajar (X2) dari Hasil perhitungan dengan SPSS versi 25 diperoleh : hasil uji linearitas berupa nilai Sig. deviation from linearity sebesar 0,66 > 0,05 maka dapat disimpulkan bahwa terdapat hubungan yang linear antara disiplin belajar dengan hasil belajar matematika kelas IV.

Hasil uji hipotesis dengan menggunakan uji regresi linier berganda sebagai berikut.

Tabel 1. Coefficients

\begin{tabular}{ccccccc}
\hline Model & \multicolumn{5}{c}{ Unstandardized Coefficients } & \multicolumn{2}{c}{$\begin{array}{c}\text { Standardized } \\
\text { Coefficients }\end{array}$} \\
& & B & Std. Error & Beta & t & Sig. \\
\hline \multirow{2}{*}{1} & (Constant) & $-16,601$ & 8,027 & & $-2,068$ & 0,043 \\
& Motivasi & 1,001 & 0,268 & 0,521 & 3,735 & 0,000 \\
& Disiplin & 0,678 & 0,290 & 0,325 & 2,333 & 0,023 \\
\hline
\end{tabular}

Hipotesis pertama dengan bantuan program SPSS versi 25 didapatkan nilai thitung sebesar 3,735 > ttabel 2,004 sehingga dapat disimpulkan bahwa variabel Motivasi Belajar (X1) berpengaruh terhadap variabel Hasil Belajar (Y). Selanjutnya untuk nilai signifikansi : dari tabel Coefficients diperoleh nilai signifikansi sebesar $0,000<0,05$, sehingga dapat disimpulkan bahwa variabel Motivasi Belajar (X1) berpengaruh secara signifikan terhadap variabel Hasil Belajar (Y) dan kemampuan variabel motivasi belajar (X1) dalam menerangkan variabel hasil belajar (Y) diperoleh sumbangan efektif variabel bebas motivasi belajar (X1) terhadap variabel terikat hasil belajar (Y) adalah sebesar 41,1\%. Sedangkan sumbangan relatif variabel motivasi belajar (X1) terhadap variabel disiplin belajar adalah sebesar $62,7 \%$ yang mengandung pengertian bahwa pengaruh variabel bebas motivasi belajar(X1) terhadap variabel terikat hasil belajar (Y) sebesar 62,7\%. 
Hipotesis kedua dengan bantuan program SPSS versi 25 didapatkan thitung sebesar 2,333 > ttabel 2,004 sehingga dapat disimpulkan bahwa variabel Disiplin Belajar (X2) berpengaruh terhadap variabel Hasil Belajar (Y). Selanjutnya untuk nilai signifikansi : dari tabel Coefficients diperoleh nilai signifikansi sebesar $0,023<0,05$, sehingga dapat disimpulkan bahwa variabel Disiplin Belajar (X2) berpengaruh secara signifikan terhadap variabel Hasil Belajar (Y) dan kemampuan variabel disiplin belajar (X2) dalam menerangkan variabel hasil belajar (Y) diperoleh sumbangan efektif variabel bebas disiplin belajar (X2) terhadap variabel terikat hasil belajar (Y) adalah sebesar 24,5\%. Sedangkan sumbangan relatif variabel disiplin belajar (X2) terhadap variabel hasil belajar adalah sebesar 37,3\% yang mengandung pengertian bahwa pengaruh variabel bebas disiplin belajar (X2) terhadap variabel terikat hasil belajar (Y) sebesar 37,3\%.

Hipotesis ketiga dengan bantuan program SPSS versi 25 didapatkan persamaan garis regresi yang terbentuk ialah $\mathrm{Y}=-16,601+1,001 X 1+0,678 X 2$ + e . Persamaan regresi tersebut diatas memperlihatkan hubungan antara variabel independent dengan variabel dependent secara parsial, konstanta sebesar -16,601 mengandung arti bahwa nilai konsisten variabel Hasil Belajar adalah sebesar -16,601, koefisien regresi $X 1$ sebesar 1,001 menyatakan bahwa setiap penambahan 1\% nilai Motivasi Belajar, maka nilai Hasil Belajar bertambah sebesar 1,571. Koefisien regresi tersebut bernilai positif, sehingga dapat dikatakan bahwa arah pengaruh variabel $X 1$ terhadap $\mathrm{Y}$ adalah positif, koefisien regresi $X 2$ sebesar 0,678 menyatakan bahwa setiap penambahan $1 \%$ nilai Disiplin Belajar, maka nilai Hasil Belajar bertambah sebesar 0,678. Koefisien regresi tersebut bernilai positif, sehingga dapat dikatakan bahwa arah pengaruh variabel $X 2$ terhadap $\mathrm{Y}$ adalah positif.

Tabel 2. Anova

\begin{tabular}{llccccc}
\hline & & Sum of & & & & \\
& Model & Squares & df & Mean Square & F & Sig. \\
\hline 1 & Regression & 7260,069 & 1 & 7260,069 & 92,059 &, $000^{\text {b }}$ \\
& Residual & 4416,362 & 56 & 78,864 & & \\
& Total & 11676,431 & 57 & & & \\
\hline
\end{tabular}

Selanjutnya pengujian signifikansi atau uji statistik regresi linear berganda digunakan uji $\mathrm{F}$, didapatkan $F$ hitung sebesar 92,059> $F$ tabel 3,16 
dan tingkat signifikansi $0,000<0,05$. Yang mengandung pengertian bahwa variabel Motivasi Belajar (X1) Disiplin Belajar (X2) berpengaruh secara positif dan signifikan terhadap variabel Hasil Belajar (Y).

Tabel 3. Model Summary

\begin{tabular}{|c|c|c|c|c|}
\hline Model & $\mathbf{R}$ & R Square & Adjusted R Square & $\begin{array}{l}\text { Std. Error of the } \\
\text { Estimate }\end{array}$ \\
\hline 1 &, $810^{\mathrm{a}}$ & 0,656 & 0,643 & 8,548 \\
\hline
\end{tabular}

Kemampuan variabel bebas dalam menerangkan variabel terikat diperoleh koefisien determinasi ( $\mathrm{R}$ square) sebesar 0,656 yang mengandung pengertian bahwa pengaruh variabel bebas motivasi belajar $(X 1)$ dan disiplin belajar (X2) terhadap variabel terikat hasil belajar $(Y)$ sebesar $65,6 \%$

\section{PEMBAHASAN}

Hasil pengujian hipotesis penelitian memberikan makna bahwa variabel bebas yang terdiri dari motivasi belajar dan disiplin belajar yang dipergunakan dalam penelitian ini secara bersama-sama maupun secara terpisah memiliki hubungan yang positif dan signifikan terhadap hasil belajar Matematika siswa kelas IV SD Negeri Gugus Bumi Waras.

Hasil penelitian yang dilakukan, diketahui bahwa motivasi belajar dan disiplin belajar peserta didik memiliki pengaruh yang positif dan signifikan terhadap hasil belajar. Hal ini memiliki kesesuaian dengan beberapa penelitian lain yang dijadikan acuan, yaitu (Warti, 2016) yang meneliti pengaruh motivasi belajar siswa terhadap hasil belajar matematika, dan penelitian yang dilakukan oleh (Mulyawati dkk, 2019) yang meneliti pengaruh disiplin belajar terhadap hasil belajar ilmu pengetahuan sosial. Pengaruh antara motivasi belajar terhadap hasil belajar dapat dilihat dari koefisien korelasi yang arahnya positif dan dikategorikan kuat, berarti semakin tinggi motivasi belajar siswa, maka diharapkan hasil belajar matematika akan semakin meningkat.

Hasil penelitian tersebut sesuai dengan pengertian motivasi yang menjelaskan motivasi adalah suatu kekuatan atau daya atau suatu keadaan yang kompleks dan kesiapsediaan dalam diri individu untuk bergerak ke arah tujuan tertentu, dan dipengaruhi oleh adanya berbagai macam kebutuhan yang hendak dipenuhi, keinginan, dan dorongan, yaitu sesuatu yang memaksa seseorang untuk berbuat atau bertindak (Khodijah, 2016). Apabila seorang 
siswa berpedoman pada dimensi-dimensi motivasi maka akan menimbulkan hasil belajar yang sangat baik untuk siswa.

Motivasi merupakan faktor penting yang harus dimunculkan dari dalam diri siswa, terlebih sistem pembelajaran yang digunakan saat ini adalah pembelajaran dalam jaringan, antara guru dan peserta didik tidak bertatap muka secara langsung, melainkan dilakukan secara jarak jauh dikarenakan situasi dan kondisi yang tidak memungkinkan untuk bertemu secara langsung karena pandemi virus covid-19, sehingga proses pembelajaran tersebut harus berlangsung atas kemauan peserta didik itu sendiri agar pembelajaran yang didapatkan menjadi lebih bermakna. Motivasi belajar dapat diartikan sebagai daya pendorong untuk melakukan aktivitas belajar tertentu yang berasal dari dalam diri dan juga dari luar individu sehingga menumbuhkan semangat dalam belajar (Monika \& Adman, 2017).

Motivasi belajar merupakan salah satu faktor yang dapat membedakan siswa yang memaksimalkan potensi belajarnya dengan siswa yang kurang berprestasi secara akademik (Garn \& Jolly, 2014). Jika seseorang memiliki motivasi terhadap suatu aktivitas maka mereka akan bisa fokus dan menyukai kegiatan tersebut. Hal tersebut menjadi acuan untuk peneliti agar motivasi selama pembelajaran dalam jaringan harus diberikan kepada guru pada saat proses pembelajaran berlangsung karena pada dasarnya motivasi mempunyai tiga fungsi yaitu, (1) mendorong timbulnya kelakuan atau suatu perbuatan. Tanpa motivasi tidak akan timbul perbuatan seperti belajar (2) sebagai pengarah, artinya mengarahkan perbuatan kepada pencapaian tujuan yang diinginkan (3) sebagai penggerak, artinya menggerakkan tingkah laku seseorang. Kuat lemahnya motivasi akan menentukan cepat atau lambatnya suatu pekerjaan.

Adapun indikator ketika peserta didik sudah memiliki motivasi yang dibangun dalam dirinya adalah sebagai berikut: yaitu (1) menyenangi tugas atau tanggung jawab pribadi; (2) menyenangi umpan balik atas tugas yang dilakukan; (3) menyenangi tugas yang bersifat moderat yang tingkat kesulitannya tidak terlalu sulit tetapi juga tidak terlalu mudah; (4) tekun dan ulet dalam bekerja; (5) penuh pertimbangan dan perhitungan; (6) keberhasilan tugas dan tetap bersikap realistis (Sarbani, 2018). 
Berdasarkan hasil penelitian motivasi memberikan sumbangan efektif yang lebih dominan dibandingkan variabel disiplin belajar sehingga guru dapat menjadikan salah satu acuan guna meningkatkan (1) minat dan perhatian terhadap pelajaran, (2) semangat untuk melakukan tugas tugas belajar, (3) tanggung jawab dalam mengerjakan tugas-tugas belajar, (4) reaksi yang ditunjukan terhadap stimulus yang diberikan, dan (5) rasa senang dan puas dalam mengerjakan tugas yang diberikan (Sudjana, 2016)

Variabel Disiplin belajar(X2) didapatkan berpengaruh yang positif dan signifikan terhadap hasil belajar. Pengaruh antara disiplin belajar dengan hasil belajar matematika mempunyai andil sebagian terhadap hasil belajar matematika dalam penelitian ini adapun hasil didapatkan koefisien korelasi yang arahnya positif, berarti semakin tinggi tingkat disiplin belajar siswa maka diharapkan hasil belajar matematika akan semakin meningkat serta disiplin belajar mempunyai pengaruh terhadap hasil belajar matematika. Dalam dunia pendidikan, kedisiplinan merupakan harga mati yang harus dibayar siswa. Pengaruh disiplin terhadap prestasi belajar sangatlah besar sehingga sangat perlu pengkondisian agar tumbuh dan berkembang sikap disiplin pada pola kehidupan siswa.

Disiplin belajar memang pada dasarnya dapat menjadi tolak ukur tingkat keberhasilan belajar siswa, yang dimana ketika siswa disiplin dalam mengatur waktu untuk belajar maka secara tidak langsung tingkat pemahaman siswa terhadap suatu materi akan meningkat karena fokus siswa tidak terbagi kedalam berbagai hal di waktu yang bersamaan hal tersebut didukung pula karena disiplin merupakan suatu tindakan yang menunjukkan perilaku tertib dan patuh pada berbagai ketentuan dan peraturan (Indrianti, 2018). bahwa kedisiplinan adalah kesediaan untuk (taat, tunduk, nurut, patuh) pada aturan, norma-norma (baik norma agama maupun norma kesusilaan) baik yang tertulis maupun tidak tertulis, baik didalam lingkungan (keluarga, sekolah dan masyarakat), merupakan arahan untuk melatih dan membentuk seseorang untuk melakukan sesuatu menjadi lebih baik.

Terlebih dengan keadaan saat ini yang dimana peserta didik diberikan kebebasan waktu untuk belajar secara mandiri dirumah tanpa adanya pengawasan dari guru secara langsung sehingga disiplin dapat menjadi acuan terhadap para guru dan orang tua agar peserta didik dapat melakukan proses 
belajar dengan maksimal. Disiplin sangat penting dalam kegiatan belajar. Sikap tersebut bisa menciptakan suasana belajar yang nyaman serta kondusif dalam proses belajar. Apabila seorang siswa memiliki sikap disiplin dalam kegiatan belajarnya, maka kepatuhan serta ketekunan belajarnya akan terus meningkat sehingga membuat hasil belajar meningkat juga. Adapun indikatorindikator yang dapat diperhatikan oleh guru dan orang tua pada peserta didik meliputi,

a. Disiplin Waktu, meliputi : (1) tepat waktu dalam belajar, mencakup datang dan pulang sekolah tepat waktu, mulai dari selesai belajar di rumah dan di sekolah tepat waktu (2) tidak meninggalkan kelas/membolos saat pelajaran (3) menyelesaikan tugas sesuai waktu yang ditetapkan. b. Disiplin Perbuatan, meliputi : (1) patuh dan tidak menentang peraturan yang berlaku (2) tidak malas belajar (3) tidak menyuruh orang lain bekerja demi dirinya (4) tidak suka berbohong (5) tingkah laku menyenangkan, mencakup tidak mencontek, tidak membuat keributan, dan tidak mengganggu orang lain yang sedang belajar. (Moenir, 2010). Sehingga disiplin menunjukkan kesadaran akan tanggung jawab serta peraturan yang berlaku baik terhadap tugas maupun peraturan yang terdapat di sekolah.

Kolaborasi antara motivasi belajar dan disiplin belajar merupakan perpaduan yang baik untuk dijadikan strategi belajar di masa pandemi covid19, karena Motivasi, Seseorang akan berhasil dalam belajar dengan baik jika pada dirinya sendiri terdapat keinginan untuk belajar dan disiplin belajar jika dijabarkan disiplin yang ada pada diri siswa secara tidak langsung akan membuat siswa menjadi konsentrasi, yang berfungsi guna memfokuskan seseorang dari beberapa perhatian menjadi fokus terhadap suatu hal dan motivasi dalam hal ini sangat membantu untuk seseorang meraih fokus. Hal ini didukung dengan tiga faktor yang membedakan minat situasional, pertama memicu minat situasional, kedua mempertahankan minat situasional menyangkut perasaan dan ketiga memelihara minat situasional sebagai nilai (Chen, Yang, \& Hsiao, 2015). Adapun teori belajar dan pembelajaran konstruktivisme cocok diterapkan pada saat pembelajaran daring karena pembelajaran konstruktivistik itu sendiri berlandaskan pada dua hipotesis yaitu, (1) pengetahuan yang dimiliki oleh seseorang merupakan hasil yang dibangun (dikonstruksi) secara aktif oleh dan dalam diri subjek belajar; bukan 
secara pasif diterima dari lingkungan belajarnya (2) peranjakan dalam memahami pengetahuan (menjadi tahu) tentang sesuatu merupakan proses adaptif (penyesuaian) yang dilakukan seseorang dalam mengorganisasikan pengalaman belajar (orang tersebut) dalam interaksinya dengan lingkungannya, bukan menemukan sesuatu di luar diri orang tersebut. Sehingga pada penelitian ini dapat menjadi acuan untuk meningkatkan mutu pendidikan itu sendiri selama diterapkannya pembelajaran dalam karingan. Peningkatan mutu pendidikan merupakan sasaran pembangunan di bidang pendidikan nasional dan merupakan bagian integral dari upaya peningkatan kualitas manusia Indonesiasecara menyeluruh (Friskilia \& Winata, 2018).

Secara garis besar hasil belajar merupakan sebagai salah satu patokan untuk mengukur keberhasilan proses pembelajaran, hasil belajar merefleksikan hasil dari proses pembelajaran yang menunjukkan sejauh mana murid, guru, proses pembelajaran, dan lembaga pendidikan telah mencapai tujuan pendidikan yang telah ditentukan (Kpolovie, Joe, \& Okoto, 2014). Perubahan hasil belajar dapat diamati, dibuktikan, dan terukur dalam kemampuan atau prestasi yang dialami oleh siswa sebagai hasil dari pengalaman belajar (Németh \& Long, 2012). Adapun faktor yang mempengaruhi hasil belajar dapat dibedakan menjadi dua yaitu faktor internal dan faktor eksternal. faktor eksternal yaitu faktor yang timbul dari luar diri siswa diantaranya guru, teman, fasilitas belajar, lingkungan sekolah, sumber belajar, pendapatan orang tua dan lain-lain. Sedangkan faktor internal yaitu faktor yang timbul dari dalam diri siswa itu sendiri diantaranya keadaan fisik, intelegensi, bakat, minat, motivasi, kemandirian, dan perhatian (Slameto, 2015).

Dalam aktivitas belajar, jika prosesnya penuh konsentrasi maka aktivitas yang dilakukan akan mencapai tujuan kemauan itu berpengaruh langsung terhadap berbagai faktor lain, seperti daya konsentrasi, perhatian, kerajinan, penemuan suatu metode yang tepat dan ketabahan dalam mengatasi kesulitan belajar (Kristin, 2016), sehingga dalam proses pembelajaran daring guru harus memperhatikan faktor-faktor penting dalam proses belajar seperti nilai-nilai, dan tujuan yang ingin dicapai dalam pada proses belajar, pilihan kegiatan untuk mengenyam pendidikan, dan ketekunan pada kegiatan belajar adalah tiga indikator penting dari motivasi belajar siswa (Wigfield \& Guthrie, 2013). 
Siswa yang belajar melalui jarak jauh dengan pembelajaran dalam jaringan yang membuat siswa harus mempunyai rasa keinginan yang kuat dan waktu yang tertib dalam proses pembelajaran, maka diharapkan akan menghasilkan suatu peningkatan dalam hasil belajar. Motivasi belajar berperan sebagai penggerak dalam diri siswa untuk belajar atas kemauannya sendiri dengan tekun serta gigih dan diiringi dengan disiplin belajar yang baik berupa pengaturan waktu yang tepat sehingga proses pembelajaran menjadi kondusif dan tertib. Sehingga kedua variabel tersebut yaitu motivasi belajar dan disiplin belajar mempunya andil yang berpengaruh terhadap hasil belajar siswa yang akan dicapai di sekolah dan dapat dirumuskan oleh guru guna mendukung selama pembelajaran dalam jaringa, karena Sebuah penelitian di Australia mengungkapkan bahwa guru dalam merencanakan pembelajaran memperhatikan keterlibatan siswa (Clarke, Clarke, Roche, \& Chan, 2015). Hasil dari penilaian ini adalah untuk mengevaluasi guru dan memberikan dukungan bagi mereka.

\section{KESIMPULAN}

Penelitian ini dilatarbelakangi oleh efek dengan diterapkannya pembelajaran dalam jaringan pada saat pandemi covid-19 dengan permasalahan rendahnya hasil belajar matematika kelas IV. Peneliti menggunakan desain korelasional yang bertujuan untuk menentukan ada tidaknya pengaruh atau hubungan dan seberapa jauh suatu pengaruh atau hubungan (yang dapat diukur) atau lebih pada masing-masing variabel motivasi dan disiplin belajar terhadap hasil belajar matematika. Berdasarkan hasil penelitian dan pembahasan mengenai pengaruh motivasi dan disiplin belajar terhadap hasil belajar peserta didik kelas IV, dapat disimpulkan bahwa: motivasi belajar dan disiplin belajar mempunyai pengaruh yang positif dan signifikan baik secara parsial maupun simultan dalam menunjang keberhasilan terhadap hasil belajar matematika Kelas IV.

\section{DAFTAR PUSTAKA}

Arikunto, Suharsimi. (2010). Prosedur Penelitian Suatu Pendekatan Praktik. Rineka Cipta, Jakarta. 
Chen, S.-C., Yang, S. J., \& Hsiao, C.-C. (2015). Exploring Student Perception, Learning Outcome and Gender Differences in a Flipped Mathematics Course. British Journal of Educational Technology . 47: 1096-1112.

Clarke, D., Clarke, D., Roche, A., \& Chan, M. C. E. (2015). Learning from Lessons: Studying the Construction of Teacher Knowledge Catalysed by Purposefully-Designed Experimental Mathematics Lessons. Mathematics Education Research Group of Australasia.

Friskilia, O., \& Winata, H. (2018). Regulasi diri (pengaturan diri) sebagai determinan hasil belajar siswa sekolah menengah kejuruan. Jurnal Pendidikan Manajemen Perkantoran (JPManper), 3(1), 36-43.

Garn, A. C., \& Jolly, J. L. (2014). High Ability Students Voice on Learning Motivation. Journal of Advanced Academic. 25: 7-24.

Hadisi, L., \& Muna, W. (2015). Pengelolaan Teknologi Informasi dalam Menciptakan Model Inovasi Pembelajaran (E-Learning). Jurnal Al-Ta'dib. 8: 117-140.

Indrianti, R., Djaja, S., \& Suyadi, B. (2018). Pengaruh Motivasi dan Disiplin Belajar Terhadap Hasil Belajar Mata Pelajaran Prakarya dan Kewirausahaan. JURNAL PENDIDIKAN EKONOMI: Jurnal Ilmiah Ilmu Pendidikan, Ilmu Ekonomi Dan IImu Sosial. 11: 69-75.

Khodijah Nyayu. (2016). Psikologi Pendidikan. Rajawali Pers, Jakarta.

Kpolovie, P. J., Joe, A. I., \& Okoto, T. (2014). Academic achievement prediction: Role of interest in learning and attitude towards school. International Journal of Humanities Social Sciences and Education (IJHSSE), 1(11), 73100.

Kristin, F. (2016). Analisis model Pembelajaran Discovery Learning dalam Meningkatkan Hasil Belajar Siswa SD. Jurnal Pendidikan Dasar Perkhasa. 2. 90-98.

Moenir, A.S. (2010). Manajemen Pelayanan Umum Di Indonesia. Bumi Aksara, Jakarta.

Molstad, C. E., \& Karseth, B. (2016). National Curricula in Norway and Finland: The Role of Learning Outcomes. European Educational Research Journal. 15: 329-344.

Monika, M., \& Adman, A. (2017). Peran efikasi diri dan motivasi belajar dalam meningkatkan hasil belajar siswa sekolah menengah kejuruan. Jurnal Pendidikan Manajemen Perkantoran, 1(1), 110-117.

Mulyawati, Y., Sumardi, S., \& Elvira, S. (2019). Pengaruh Disiplin Belajar Terhadap Hasil Belajar Ilmu Pengetahuan Sosial. Pedagonal: Jurnal Ilmiah Pendidikan. 3. 01-14.

Németh, J., \& Long, J. G. (2012). Assessing learning outcomes in US planning studio courses. Journal of planning education and research, 32(4), 476-490.

Pane, A., \& Dasopang, M. D. (2017). Belajar dan pembelajaran. Fitrah: Jurnal Kajian Ilmu-Ilmu Keislaman. 3: 333-352.

Sarbani, Y. A., \& Subandoro, P. S. (2018). Memahami Motivasi Berprestasi dan Manfaat Penggunaan Gawai Bagi Generasi Digital Native. VOCATIO: Jurnal Ilmiah Ilmu Administrasi dan Sekretaris. 1: 32-45.

Slameto. (2015). Belajar \& Faktor-Faktor yang Mempengaruhi. Rineka Cipta, Jakarta.

Sudjana, Nana. (2016). Penilaian Hasil Proses Belajar Mengajar. Remaja Rosdakarya, Bandung. 
Sugiyono. (2014). Metode Penelitian Pendidikan Pendekatan Kuantitatif, Kualitatif, dan $R \& D$. Alfabeta, Bandung.

Susanto, Ahmad. (2013). Teori Belajar \& Pembelajaran di Sekolah Dasar. Prenada Media Group, Jakarta.

Warti, E. (2016). Pengaruh Motivasi Belajar Siswa terhadap Hasil Belajar Matematika Siswa di SD Angkasa 10 Halim Perdana Kusuma Jakarta Timur. Mosharafa: Jurnal Pendidikan Matematika. 5:177-185.

Wigfield, A., \& Guthrie, J. T. (Eds.). (2013). Motivation for reading: individual, home, textual, and classroom perspectives: a special issue of educational psychologist. Routledge, London.

Yuristia, A. (2018). Pendidikan sebagai transformasi kebudayaan. IJTIMAIYAH Jurnal Ilmu Sosial Dan Budaya. 1:1-5.

Zhou, G., Chen, S., \& Chen, Z. (2020). Back to the Spring of Wuhan: Facts and Hope of COVID-19 Outbreak. Journal Frontiers of Medicine. 14: 113-116. 